Relations industrielles

Industrial Relations

\title{
Predictors of Participation in Voluntary Vocational Training
} An Empirical Study among Canadian Female and Male Managers

Les déterminants de la participation à la formation professionnelle volontaire : une étude auprès de cadres féminins et masculins dans les entreprises canadiennes

Predictores de la participación al entrenamiento vocacional voluntario : un estudio empírico entre gestionarios canadienses hombres y mujeres

Julie Cloutier, Stéphane Renaud et Lucie Morin

Volume 63, numéro 2, 2008

URI : https://id.erudit.org/iderudit/018576ar

DOI : https://doi.org/10.7202/018576ar

Aller au sommaire du numéro

Éditeur(s)

Département des relations industrielles de l'Université Laval

ISSN

0034-379X (imprimé)

1703-8138 (numérique)

Découvrir la revue

Citer cet article

Cloutier, J., Renaud, S. \& Morin, L. (2008). Predictors of Participation in Voluntary Vocational Training: An Empirical Study among Canadian Female and Male Managers. Relations industrielles / Industrial Relations, 63(2), 268-289. https://doi.org/10.7202/018576ar

\section{Résumé de l'article}

Dans de nombreuses entreprises canadiennes, les travailleurs sont de plus en plus encouragés par leur employeur à se développer par eux-mêmes de façon volontaire, hors des activités de formation obligatoire. Ce type particulier de formation externe réfère à la formation professionnelle volontaire (vocational voluntary training). Il existe très peu d'études portant sur les déterminants de la participation à la formation professionnelle volontaire. Les travaux de Renaud, Morin et Cloutier (2006) figurent parmi les rares études à s'être penchées sur la question. Réalisée au sein d'une organisation du secteur bancaire canadien, leur étude rèvèle notamment que les femmes cadres présentent un probabilité plus élevée de participer à la formation professionnelle volontaire que leurs homologues masculins. Elle met également en évidence l'effet differencié selon le sexe des facteurs de productivité (ex. : âge, scolarité, nombre d'années de service). En vue d'expliquer la participation supérieure des femmes à ce type de formation, ces mêmes chercheurs ont avancé l'hypothèse selon laquelle les femmes utiliseraient ce type de formation pour compenser le manque de formation obligatoire.

A partir des données nationales de l'Enquête sur le milieu de travail et les employés (EMTE) (Workplace and Employee Survey - WES) de Statistique Canada, notre étude vise a identifier les déterminants de la participation a la formation professionnelle volontaire de cadres masculins et féminins, respectivement. Trois objectifs specifiques sont visés : 1) vérifier l'effet differenciè des facteurs de capital humain (âge, scolarité, annees de service) sur la participation des cadres masculins et féminins grâce à des données nationales, ce qui assure une meilleure généralisation des résultats, 2) vérifier empiriquement si la formation professionnelle volontaire joue un rôle compensatoire pour les femmes, et 3 ) elargir le modèle d'analyse aux obstacles à la formation professionnelle volontaire en vérifiant empiriquement influence qu'exercent les responsabilités familiales.

En s’appuyant sur la théorie du capital humain, la théorie de la discrimination systémique et la théorie du conflit travail-famille, six hypothèses de recherche ont eté formulées. Les resultats d'une régression logistique indiquent que la scolarité, le nombre d'annees de service et le fait d'avoir un conjoint(e) ameliorent la probabilite des cadres de participer à la formation professionnelle volontaire. En revanche, l'âge et le fait d'avoir au moins un enfant d'âge préscolaire ont une influence nègative sur la participation. De plus, lorsque Yon controle leffet de ces variables, les emmes demeurent plus susceptibles de suivre de la formation professionnelle volontaire que les hommes.

Les résultats montrent ainsi que la participation plus importante des femmes à la formation professionnelle volontaire ne s'explique pas entierement par le fait que les hommes et les femmes possèdent des caracteristiques differentes (facteurs de productivité, formation obligatoire et responsabilites familiales). A ce chapitre, les resultats des régressions logistiques respectivement effectuées pour les hommes et les femmes montrent que la différence de participation observée s'explique largement par l'effet différencié qu'exercent ces caractéristiques. Pour les hommes,

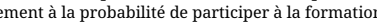
professionnelle volontaire. Pour les femmes, la probabilité de suivre ce type de formation varie en fonction : 1) de l'âge, 2) du nombre d'années de service, 3) du niveau de scolarité, 4) de la participation à la formation obligatoire, 5) du fait d'avoir au moins un enfant de moins de 12 ans et 6 ) du fait d'avoir un conjoint(e). Ces résultats suggèrent que les hon et les fer cadres ant une

Pour les femmes, les résultats suggèrent ainsi que les jeunes femmes retarderaient leur investissement dans la formation professionnelle volontaire parce qu'elles anticipent d'interrompre leur carrière pour se consacrer à la maternite. En lien avec la thêorie de la discrimination systémique, les résultats suggèrent que les femmes plus âgée participeraient moins à ce type de formation parce qu'elles percevraient moins de possibilités d'avancement de carrière, ou par. qu et aux hommes. Toujours en lien avec la theorie de la discrimination systemique, les resultats obtenus en regard des stráécie visant à contrer les effets des praticues discriminatoires de leur employeur à travers la surqualifiction rísultats obtenus concernant le niveau de scolarité sont également cohérents avec la théorie de la discrimination

Par ailleurs, les résultats suggèrent que les femmes participeraient à la formation professionnelle volontaire notamment pour compenser la formation obligatoire qu'elles n'ont pas reçue de leur employeur. La formation prefession sexnifictes a professionnelle volontaire.
Tous droits réservés (C Département des relations industrielles de l'Université Laval, 2008
Ce document est protégé par la loi sur le droit d'auteur. L’utilisation des services d'Érudit (y compris la reproduction) est assujettie à sa politique d'utilisation que vous pouvez consulter en ligne.

https://apropos.erudit.org/fr/usagers/politique-dutilisation/ 


\title{
Predictors of Participation in Voluntary Vocational Training
}

\section{An Empirical Study among Canadian Female and Male Managers}

\author{
Julie Cloutier \\ STÉPHANe Renaud \\ LUCIE MORIN
}

Using Canadian national data from the Workplace and Employee Survey (WES), this study aims to identify predictors of participation in voluntary vocational training for female and male managers, respectively. Results show a higher rate of participation for female managers and a differential effect of predictors by gender. For men, schooling is the sole human capital variable significantly linked to the probability of participating in voluntary vocational training. For women, the probability of participating in voluntary vocational training varies by age, organizational tenure and schooling. Results also indicate that both participation in mandatory training and family responsibilities are significantly and negatively linked to participation in voluntary training for female managers but not for male managers.

The development and maintenance of workers' skills has become a key issue for most companies (Grant and Hugues, 2007). From an economic standpoint, training and development activities are an effective means to improve both individual and organizational productivity (Wexley and

- Cloutier, J., Département Organisation et Ressources humaines, École des sciences de la gestion, Université du Québec à Montréal, Montréal, Québec, cloutier.julie@uqam.ca

- Renaud, S., École de relations industrielles, Université de Montréal, Montréal, Québec, stephane.renaud@umontreal.ca

- Morin, L., Département Organisation et Ressources humaines, École des sciences de la gestion, Université du Québec à Montréal, Montréal, Québec, morin.lucie@uqam.ca 
Latham, 2002). From a social perspective, training allows workers to update their human capital, thus ensuring them a better value on the labour market (St-Onge et al., 2004).

In the wake of the numerous transformations taking place in organizations nowadays and the increased accountability of workers for their human capital, employers are encouraging employees more than ever to develop their skills on their own and on a voluntary basis outside of mandatory training activities. In the organizational training literature, this development effort refers to the concept of continuous learning within organizational settings (see Birdi, Allan and Warr, 1997; Maurer and Shore, 2002; Maurer and Tarulli, 1994). In the present study, this concept is labelled "voluntary vocational training" and refers to any type of structured learning, linked to the career, taken on the employee's own time and which does not require the employer's approval (e.g., a credited undergraduate course on finance). In other words, voluntary vocational training refers exclusively to external voluntary training activities. This type of training activities differs from internal non-mandatory training (e.g., a seminar on stress management) as well as from mandatory training (internal or external) (e.g., a training program on negotiating a contract) which are both training activities organized and paid for by the employer and where the employee usually takes part during working hours.

The increase in adult registrations for credited university courses (AUCC, 2007) suggests that voluntary vocational training activities are popular among workers. However, very little is known on the subject. In fact, the scientific literature only mentions a few studies on determinants of participation in voluntary vocational training (see Birdi, Allan and Warr, 1997; Miller, 1994; Tharenou, 2001). Briefly, results show that, ceteris paribus, women participate more actively than men, and that both training motivation based on expectation and the perceived environment (e.g., company policies and supervisory support) explain participation in voluntary vocational training. However, in these studies, statistical analyses do not distinguish between internal activities endorsed by the employer and external voluntary vocational training activities. Therefore, it is not possible to determine the specific determinants for each type of voluntary vocational training.

The recent empirical study conducted by Renaud, Morin and Cloutier (2006) within an organization of the Canadian banking sector exclusively focuses on external voluntary vocational training (credited university courses taken on the employees' personal time). Results show that managers participate more in voluntary vocational training than non-managers, and that female managers have a greater participation rate than male managers. This implies that "the probability of participating in voluntary training varies 
according to gender and managerial status. This probability is explained in particular by the differential effect produced by the individuals' productivityrelated characteristics (age, schooling, organizational tenure and part-time status) according to gender and managerial status" (p. 675). Furthermore, the authors suggest that the four sub-groups studied (male managers, female managers, male non-managers and female non-managers) participate in voluntary training in different proportions because of their different assessments of the marginal utility of voluntary training. They go further by proposing an alternative theoretical explanation for their results: in general, women receive less mandatory training than men and use voluntary training to compensate for and to address their lack of skill. However, the Renaud, Morin and Cloutier (2006) study has certain limitations. First, the data used was compiled from only one company, which limits the generalization of the results. Second, the data does not make it possible to control for mandatory training received by each employee. Finally, the analysis model concentrates on only one type of predictors-levels of human capital. In particular, obstacles to participation are excluded.

The broad objective of this study is to identify predictors of participation in voluntary vocational training for male and female managers, respectively. The manager population was selected for the following two reasons. First, managers perform tasks that are increasingly complex and performance on these tasks requires, in general, a great amount of various skills, which development is often not filled by the employer. Second, in most organizations, managers are the ones having the most opportunities for salary and career progression (Noe, 1996). Thus, this category of employees should have a high interest in voluntary vocational training activities compared with, for instance, technical or office employees who acquire most of their skills during formal schooling.

In line with the above general objective, this study also has three specific objectives. First, this study aims to improve on the work of Renaud, Morin and Cloutier (2006) by expanding the scope of the surveyed population of managers from a single firm to a national level which will help to improve generalization. Second, this study aims to empirically test the compensatory role of voluntary vocational training for women. This test has never been done to our knowledge. Last, this study aims to examine the link between family responsibilities and participation in voluntary vocational training. Because voluntary vocational training is taken during one's own free time, it seems important to include that variable in the analysis model.

This research offers many original contributions. By investigating voluntary vocational training, we add to the existing body of training literature, which has been mainly devoted to mandatory training or voluntary vocational training organized by the employer (see Birdi, 
Allan and Warr, 1997). External voluntary vocational training activities are growing and research needs to support this trend with the creation of knowledge. Furthermore, the integration of both mandatory training and family responsibilities in the conceptual model provides a better test than a model focusing only on human capital variables. Last, as it appears that the proportion of female managers will increase in the future, there is a need to better understand the link between predictors of training participation for this particular category of employees.

\section{CONCEPTUAL FRAMEWORK}

In numerous studies investigating education and training, human capital theory (Becker, 1962) has been used to better understand decision making from both an employer's perspective (supply side) and an employee'sperspective (demand side). This article focuses on voluntary training which falls under the demand side. From that perspective, workers invest in training to improve their productivity in order to increase their benefits, in particular their salary. Further, the decision of an individual to take training is based on the analysis of the cost/benefit ratio of said training. Therefore, the factors that increase training costs or reduce benefits have a negative impact on training participation. This theory predicts that, all things being equal, age, tenure and schooling, all of which proxy for certain types of human capital, have a negative impact on training investment.

In addition, according to the theory of systemic discrimination, social values, sexist prejudices and stereotypes are integrated in the decision making process and in the operational rules of organizations which give rise to inequalities between men and women (Chicha, 1997; Doeringer and Piore, 1971). Consequently, women obtain a lower return on investment compared to men for their work experience, schooling, tenure and training. In line, results of empirical studies show that for the same characteristics linked to productivity, women earn lower salaries than men (Arulampalam, Booth and Bryan, 2007; Baker and Fortin, 2004; Blau and Kahn, 2006; Gunderson, 2006; Statistique Canada, 2002). Furthermore, other studies show that women have to deal with the glass ceiling phenomenon, meaning that they are victims of systemic discrimination with respect to promotions into the higher echelons of management (Ginther and Hayes, 2003; McDowell, Singell and Ziliak, 2001; Olson and Becker, 1983; Swimmer, 1990). Therefore, and in line with the first objective of our study, we put forward the following three hypotheses:

H1a: There is a negative link between age and participation in voluntary vocational training and this link is stronger for women managers than for male managers. 
H1b: There is a negative link between organizational tenure and participation in voluntary vocational training and this link is stronger for women managers than for male managers.

H1c: There is a negative link between schooling and participation in voluntary vocational training and this link is stronger for women managers than for male managers.

The second objective of this study is to test whether voluntary vocational training plays a compensating role for women. Individuals are likely to improve their productivity through two types of training: mandatory and voluntary training (Goldstein and Ford, 2002; Noe, 2005; Wexley and Latham, 2002). The first type of training refers to organized learning activities paid for by the employer in order to improve the skills of the individuals in their present position (training) or future position (development). As explained in the introduction, voluntary vocational training refers to learning activities undertaken by employees who personally organize their training by taking, for example, courses given through the Internet or by learning institutions. This type of training may be considered as a valid substitute to mandatory training, as suggested by the results obtained by Renaud, Morin and Cloutier (2006). In fact, when a manager is not selected by their employer to receive mandatory training, we can assume that this manager can personally invest in training to fulfil their own human capital needs. Accordingly, receiving mandatory training would have a negative impact on participation in voluntary vocational training.

To explain the differential participation of men and women in voluntary vocational training, Renaud, Morin and Cloutier (2006) formulate the hypothesis of a compensatory role played by voluntary vocational training for women. They argue that the glass ceiling phenomenon limits the access of women to mandatory training. Studies on the subject show that, ceteris paribus, women receive less mandatory training then men (Booth, 1991; Green, 1993; Miller, 1994). Women would then try to compensate for the lack of mandatory training by undertaking voluntary vocational training, in as much as they think that this training will benefit their career. Therefore, we propose the following hypothesis:

$\mathrm{H} 2$ : $\quad$ There is a negative link between mandatory training and participation in voluntary vocational training and this link is stronger for female managers than for male managers.

The third objective of this study is to verify the link between family responsibilities and voluntary vocational training. Our argument is based on the work-family conflict theory, which states that individuals must share a limited amount of time and energy between various paid and non-paid activities. The work-family conflict then translates into a difficulty assuming 
various roles pertaining to public and private life (Mark, 1977). Time spent on the first activities produces a negative influence on the second activities and vice versa. Factors that influence the work-family conflict include the fact of allocating the same importance to work and family (Greenhaus et al., 1989), the lack of support in the home (Lorech, Russel and Rush, 1989), and the presence of children (Voydanoff, 1988; Lorech, Russel and Rush, 1989).

Since voluntary vocational training takes place outside of working hours, it therefore requires an added investment in terms of personal time. As a result, one can argue that family responsibilities would have a negative impact on participation in this type of training. In line, Oosterbeek (1998) results show that time constraints represent the main obstacles linked to training requests. Moreover, although the schooling level of women is increasing and their participation in the labour force has grown over the past decades, they continue to bear most family responsibilities (Bianchi et al., 2000; Marshall, 2006). For men, on the other hand, having children does not necessarily mean family responsibilities. Thus, women tend to experience more acutely a work-family conflict than men (see Eby et al., 2005). Therefore and in line with the third specific objective of this study, we put forward the following hypothesis:

H3a: There is a negative link between family responsibilities and participation in voluntary vocational training and this link is stronger for female managers than for male managers.

Finally, the work-family conflict theory suggests that the presence of a spouse allows women to reduce their family responsibilities and frees up some time to participate in, among other things, voluntary vocational training. However, as men still do not play a major role in domestic duties, all things being equal, the fact of having a spouse should have less effect on their free time than for women. Thus, we formulate the following hypothesis:

$\mathrm{H} 3 \mathrm{~b}$ : There is a positive link between having a spouse and participation in voluntary vocational training and this link is stronger for female managers than for male managers.

\section{METHODOLOGY}

\section{Data}

The data for our study was taken from the micro data bank on workers of the Workplace and Employee Survey (WES) of Statistics Canada for the year 2003. This survey deals with various aspects of the workplace and allows for the exploration of questions pertaining to voluntary vocational training. 
The target population of this survey is made up of all employees of business locations operating in Canada (Statistics Canada, 2003). The sample was selected using the stratified random sampling method using strata defined by 1) industry, 2) region and 3) size of the business location workforce. For the year 2003, a total number of 20834 employees were surveyed. For the purpose of our study, only full-time permanent managers were included. After weighting the data, ${ }^{1}$ our final sample totalled 2491 full-time permanent managers of which $36 \%$ are women.

\section{Measures}

Our dependant variable, participation in voluntary vocational training, is measured using a dummy variable coded 1 if a manager, in the past twelve months, has taken any career-related courses not sponsored by his employer. This variable is coded 0 otherwise. This dummy variable was created from the following question: "In the past twelve months, have you taken any courses that were not sponsored by your employer but were career-related?"2

Gender is measured by a dummy variable coded 1 for women and 0 for men.

Human capital variables used in this study include age, schooling and organizational tenure. For age, from the year of birth of the managers, we created four dummy variables coded 1 if age is less then 30 , between 30-39 or 40-49. The age reference category is managers aged 50 and over. For schooling, we created four dummy variables coded 1 if the most senior diploma obtained is a community college degree, an undergraduate degree (ex.: university certificate, bachelor) or a graduate degree (ex.: master or doctorate). The schooling reference category is high school or less. For organizational tenure, based on manager's date of employment, we created a continuous variable which reflects the number of years of tenure within the organization, and its squared term.

Mandatory training is measured using a dummy variable coded 1 if a manager has received, in the past twelve months, any job-related training provided or paid by his employer. This variable is coded 0 otherwise.

Family responsibilities are measured using the presence of children as well as the presence of a spouse. For children, two dummy variables were created: First, child(ren) aged 5 and under, is coded 1 if a manager has at least one child aged 5 and under, 0 otherwise. Then, child(ren) 6-12,

1. In this study, all statistical procedures were performed using a sampling weight provided by Statistics Canada. This weight was reduced to the sampling size.

2. The questionnaire and the reporting guide are available on $<$ http://www.statcan.ca $>$. 
is coded 1 if a manager has at least one child aged between 6 and 12, 0 otherwise. With regard to spouse, this variable was coded 1 for managers legally married and not separated or living with a common-law partner, 0 otherwise.

\section{RESULTS}

Table 1 presents descriptive statistics obtained for the set of variables studied. In order to test our hypotheses, we used logistic regressions to estimate the probability of participating in voluntary vocational training during the course of a year for the full sample, female managers and male managers, respectively. Results of these regressions are presented in Table 2. A Likelihood ratio test (LR Test) confirms that the femalemanager sample and the male-manager sample can be separated $\left(\mathrm{X}^{2}=83.77\right.$, df $=12, \mathrm{p}<.01)$.

TABLE 1

Descriptive Statistics for Variables under Study

\begin{tabular}{|c|c|c|c|c|c|c|}
\hline & \multicolumn{2}{|c|}{ Full sample } & \multicolumn{2}{|c|}{ Women } & \multicolumn{2}{|c|}{ Men } \\
\hline & Mean & $\begin{array}{c}\text { Std. } \\
\text { deviation }\end{array}$ & Mean & $\begin{array}{c}\text { Std. } \\
\text { deviation }\end{array}$ & Mean & $\begin{array}{c}\text { Std. } \\
\text { deviation }\end{array}$ \\
\hline Aged less than 30 & 0.078 & - & 0.098 & - & 0.067 & - \\
\hline Aged 30 to 39 & 0.289 & - & 0.274 & - & 0.298 & - \\
\hline Aged 40 to 49 & 0.338 & - & 0.400 & - & 0.303 & - \\
\hline Age $50+$ & 0.294 & - & 0.228 & - & 0.332 & - \\
\hline High school or less & 0.296 & - & 0.245 & - & 0.326 & - \\
\hline Community College degree & 0.275 & - & 0.309 & - & 0.255 & - \\
\hline Undergraduate degree & 0.310 & - & 0.334 & - & 0.297 & - \\
\hline Graduate degree & 0.119 & - & 0.112 & - & 0.123 & - \\
\hline Organizational Tenure & 10.008 & 8.813 & 9.379 & 8.677 & 10.369 & 8.873 \\
\hline Gender (women) & 0.360 & - & & & & \\
\hline Mandatory Training & 0.430 & - & 0.430 & - & 0.430 & - \\
\hline Spouse & 0.790 & - & 0.713 & - & 0.834 & - \\
\hline Child(ren) aged 5 and under & 0.170 & - & 0.177 & - & 0.169 & - \\
\hline $\begin{array}{l}\text { Child(ren) aged between } 6 \\
\text { and } 12\end{array}$ & 0.156 & - & 0.126 & - & 0.174 & - \\
\hline Voluntary vocational training & 0.090 & - & 0.117 & - & 0.073 & - \\
\hline $\mathrm{N}$ & \multicolumn{2}{|c|}{2491} & \multicolumn{2}{|r|}{909} & \multicolumn{2}{|c|}{1582} \\
\hline
\end{tabular}

For the significance of the models, Table 2 shows that variables in the three equations globally offer a significant contribution to the predicted participation in voluntary vocational training (the $\mathrm{p}$ values for chi-square are significant at the $\alpha=.01$ level). 
TABLE 2

Logistic Regressions on Voluntary Vocational Training Unstandardized Coefficients and Exponentiated Coefficients (Odds Ratios) (Standard Errors in Brackets)

\begin{tabular}{|c|c|c|c|c|c|c|}
\hline & \multicolumn{2}{|c|}{ Full sample } & \multicolumn{2}{|c|}{ Women } & \multicolumn{2}{|c|}{ Men } \\
\hline & $\beta$ & $\operatorname{Exp}(\beta)$ & $\beta$ & $\operatorname{Exp}(\beta)$ & $\beta$ & $\operatorname{Exp}(\beta)$ \\
\hline \multirow[t]{2}{*}{ - Aged less than 30} & 0.407 & 1.503 & -0.061 & 0.941 & 0.444 & 1.558 \\
\hline & \multicolumn{2}{|c|}{$(0.412)$} & \multicolumn{2}{|c|}{$(0.844)$} & \multicolumn{2}{|c|}{$(0.491)$} \\
\hline \multirow[t]{2}{*}{ - Aged 30 to 39} & $1.443 * * *$ & 4.234 & $2.308 * * *$ & 10.057 & $0.515^{*}$ & 1.673 \\
\hline & \multicolumn{2}{|c|}{$(0.236)$} & \multicolumn{2}{|c|}{$(0.409)$} & \multicolumn{2}{|c|}{$(0.307)$} \\
\hline \multirow[t]{2}{*}{ - Aged 40 to 49} & $0.706 * * *$ & 2.025 & $1.403 * * *$ & 4.067 & -0.318 & 0.728 \\
\hline & \multicolumn{2}{|c|}{$(0.209)$} & \multicolumn{2}{|c|}{$(0.350)$} & \multicolumn{2}{|c|}{$(0.304)$} \\
\hline \multirow[t]{2}{*}{ - Community College } & $1.356^{* * * *}$ & 3.881 & $0.855^{* *}$ & 2.353 & $1.312^{* * *}$ & 3.713 \\
\hline & \multicolumn{2}{|c|}{$(0.241)$} & \multicolumn{2}{|c|}{$(0.433)$} & \multicolumn{2}{|c|}{$(0.306)$} \\
\hline \multirow[t]{2}{*}{ - Undergraduate Degree } & $1.058 * * *$ & 2.881 & $1.091 * *$ & 2.978 & $0.813^{* *}$ & 2.255 \\
\hline & \multicolumn{2}{|c|}{$(0.248)$} & \multicolumn{2}{|c|}{$(0.432)$} & \multicolumn{2}{|c|}{$(0.320)$} \\
\hline \multirow{2}{*}{ - Graduate Degree } & $1.370 * * *$ & 3.935 & 0.807 & 2.240 & $1.545^{* * *}$ & 4.686 \\
\hline & \multicolumn{2}{|c|}{$(0.284)$} & \multicolumn{2}{|c|}{$(0.525)$} & \multicolumn{2}{|c|}{$(0.347)$} \\
\hline \multirow[t]{2}{*}{ - Organizational Tenure } & -0.014 & 0.986 & 0.003 & 1.003 & -0.006 & 0.994 \\
\hline & \multicolumn{2}{|c|}{$(0.025)$} & \multicolumn{2}{|c|}{$(0.044)$} & $(0.0$ & \\
\hline - Organizational Tenure & $0.002 * * *$ & 1.002 & $0.003 * *$ & 1.003 & 0.000 & 1.000 \\
\hline Squared & $(0.0$ & & $(0.0$ & & $(0.0$ & \\
\hline - Gender (women) & $\begin{array}{r}0.396 * * * \\
(0.1\end{array}$ & 3) 1.486 & & & & \\
\hline - Mandatory Training & -0.108 & 0.897 & $-0.583 * *$ & 0.558 & -0.163 & 0.850 \\
\hline & $(0.1$ & & $(0.2$ & & $(0.2$ & \\
\hline - Spouse & $0.693 * * *$ & 2.000 & $1.246^{* * * *}$ & 3.478 & 0.084 & 1.087 \\
\hline & $(0.22$ & & $(0.3$ & & $(0.3$ & \\
\hline - Child(ren) aged 5 and under & $-1.235 * * *$ & 0.291 & $-2.706 * * *$ & 0.067 & -0.380 & 0.684 \\
\hline & $(0.2$ & & $(0.6$ & & $(0.3$ & \\
\hline - Child(ren) aged between 6 & -0.351 & 0.704 & $-1.455 * * *$ & 0.233 & $0.458^{*}$ & 1.581 \\
\hline and 12 & $(0.2$ & & $(0.4$ & & $(0.2$ & \\
\hline Constant & $-4.812 * * *$ & 0.008 & $-5.256 * * *$ & 0.005 & $-3.587 * * *$ & 0.028 \\
\hline & $(0.3$ & & $(0.6$ & & $(0.4$ & \\
\hline Chi-square & 168.3 & $1 * * *$ & 195.2 & $3 * * *$ & 44.2 & 0 0*** \\
\hline $\mathrm{N}$ & 245 & & 90 & & 15 & \\
\hline
\end{tabular}

$*: \mathrm{p}<0.10 ; * *: \mathrm{p}<0.05 ; * * *: \mathrm{p}<0.01$ (two-tailed t-tests)

Note : Reference categories are : aged 50 and over for age and high school or less for schooling.

In the full sample, schooling, organizational tenure and having a spouse increase the probability of participating in voluntary vocational training, whereas age and having at least one child of preschool age both have a negative effect on participating in voluntary vocational training. However, when we control for all variables, the estimated coefficient for gender 
remains significant $(\mathrm{p}<.01)$ and shows that, ceteris paribus, the fact of being a woman increases the odds of participating in voluntary vocational training $(\beta=.396)$ by about $50 \%(\operatorname{Exp}(B)=1.486)$. Accordingly, results show that men and women have a differential participation in voluntary vocational training.

\section{Human Capital Variables}

Age. ${ }^{3}$ As the estimated equation for male managers ${ }^{4}$ indicates, the estimated coefficients for each age group are not significantly different from zero $(\mathrm{p}>.05)$. Therefore, the participation of male managers in voluntary vocational training does not vary in relation to their age. This result suggests that the cost/benefit ratio associated with voluntary vocational training remains stable during the working life of male managers.

On the other hand, the results obtained for female managers show that age presents a concave function. ${ }^{5}$ Women aged 30 to 49 are more likely to take voluntary vocational training than those who are younger or older. Specifically, all things being equal, women aged 30 to 39 are 10 times more likely to take voluntary vocational training than women who are less than 30 years old or aged 50 and more $(\beta=2.308, p<.01)$. For women aged 40 to 49 , the odds of participating in voluntary vocational training are multiplied by four $(\beta=1.403, p<.01)$. A test on the difference of the estimated coefficients ${ }^{6}$ for women and men provides significant and positive results for the age group 30 to $39(\mathrm{t}=3,51)$ and for the age group 40 to 49 $(t=2,34)$, indicating a more pronounced effect of age on participation to voluntary vocational training for female managers than for male managers. In short, for female managers, the marginal utility for voluntary vocational training decreases gradually after age 39 while it remains constant for male managers. Thus, our results support the hypothesis whereby age is more negatively related to the taking of voluntary vocational training for women than for men.

Organizational Tenure. The estimated coefficients ${ }^{7}$ for the variables organizational tenure and organizational tenure squared are not significant for male managers $(p>.05)$. Whatever the number of years of tenure

3. We also run three regressions with age as a continuous variable. Results were similar.

4. The results are similar when tenure is excluded from the equation.

5. Tests were performed on the coefficient differences to verify if there were differences between the estimated coefficients for the age groups. $t=\left(b_{\text {age,female }}-b_{\text {age,male }}\right) /\left[v r_{b \text { age,female }}\right.$ + var $\left._{\mathrm{b} \text { age,male }}\right]^{1 / 2}$.

6. $\mathrm{t}=\left(\mathrm{b}_{\mathrm{x}, \mathrm{female}}-\mathrm{b}_{\mathrm{x}, \mathrm{male}}\right) /\left[\mathrm{var}_{\mathrm{bx}, \mathrm{female}}+\mathrm{var}_{\mathrm{bx}, \text { male }}\right]^{1 / 2}$.

7. The results remain similar when age is excluded from the equation. 
within an organization, their odds of participating in voluntary vocational training remain unchanged. However, contrary to the premise of Hypothesis $1 \mathrm{~b}$, organizational tenure has a significant positive influence, although very weak, on women's participation in voluntary vocational training $(\beta=.003, \mathrm{p}<.01)$. Female managers improve their odds of participating in voluntary vocational training by $3 \%$ per 10 -year range of tenure within an organization. We therefore reject Hypothesis $1 \mathrm{~b}$, which stipulated that organizational tenure is more negatively related to voluntary vocational training participation for women than for men.

Schooling. For male managers, schooling has a positive influence on the probability of participating in voluntary vocational training $(\mathrm{p}<.05)$. When they complete their formal education beyond "high school" (community college, undergraduate or graduate degree), their odds of participating in voluntary vocational training increase between two and four times compared to men who only obtain a high school diploma.

With respect to female managers, schooling has a concave effect on their participation in voluntary vocational training $(\mathrm{p}<.05)$. Those who only have a high school diploma or a graduate degree have less chance of participating in voluntary vocational training than those who hold a community college degree or an undergraduate degree. In fact, female managers who hold a community college degree or an undergraduate degree more than double their odds of participating in voluntary vocational training compared to others.

A test on the estimated difference of the coefficients ${ }^{8}$ for men and women show negligible results indicating that a community college or undergraduate degree result in a similar effect on the participation of men and women $(\mathrm{t}=-0.86192$ and $\mathrm{t}=0.517104)$. In brief, contrary to what we had anticipated, schooling is positively linked to the participation of managers involuntary vocational training and this positive relation is slightly stronger for male managers and shows up amongst holders of a graduate degree. We therefore dismiss Hypothesis 1c.

\section{Mandatory Training}

Findings show that there is no link between having received mandatory training, and male managers participating in voluntary vocational training $(\mathrm{p}>.05)$. However, for female managers, mandatory training is negatively and significantly related to the taking of voluntary vocational training $(\beta=-.583, \mathrm{p}<.05)$. Women who did not receive mandatory training are two times more likely to take voluntary vocational training than those who

8. $\mathrm{t}=\left(\mathrm{b}_{\mathrm{x}, \mathrm{female}}-\mathrm{b}_{\mathrm{x}, \text { male }}\right) /\left[\mathrm{var}_{\mathrm{bx}, \mathrm{female}}+\mathrm{var}_{\mathrm{bx}, \text { male }}\right]^{1 / 2}$. 
have participated in mandatory training. These results provide support to Hypothesis 2, whereby mandatory training is more negatively related to voluntary vocational training participation for female managers compared to male managers.

\section{Family Responsibilities}

For male managers, the estimated coefficients for the variables Child(ren) aged 5 and under and Child(ren) aged between 6 and 12 are not significant $(\mathrm{p}>.05)$. Family responsibilities are therefore not linked to the participation of male managers in voluntary vocational training. For female managers, results show that women with child(ren) five and under are nearly 15 times less disposed to take voluntary vocational training than women without child(ren) $(\beta=-2.706, \mathrm{p}<.01)$. Women who have child(ren) aged between 6 and 12 see their odds of participating in voluntary vocational training being divided by four $(\beta=-1.455, \mathrm{p}<.01)$. Thus, we accept Hypothesis $3 \mathrm{a}$.

Hypothesis $3 \mathrm{~b}$ predicted that the fact of having a spouse is positively and more strongly linked to women's participation than to men's. Findings show that this variable is not linked to male managers' participation $(p>.05)$. However, having a spouse is a significant predictor of participation in voluntary vocational training for female managers $(\beta=1.246, p<.01)$. Women who have a spouse increase their odds of participating in voluntary vocational training by a factor of 3.5 , ceteris paribus. We therefore accept Hypothesis $3 b$.

\section{INTERPRETATION OF RESULTS AND DISCUSSION}

The main objective of our study was to identify predictors of participation in voluntary vocational training for male and female managers, respectively. Results show that Canadian female managers participate to a greater extent in voluntary vocational training than male managers, which supports previous findings obtained by Renaud, Morin and Cloutier (2006) in the banking sector. Specifically, results show that the proportion of female managers who take part in voluntary vocational training is $60 \%$ greater compared to males managers.

Findings obtained from the full sample show that the studied variables, with the exception of mandatory training and the presence of children aged 6 to 12 , significantly predict the probability of managers taking part in voluntary vocational training. However, when all variables are controlled for, women continue to participate in voluntary vocational training in a greater proportion than do men. 
Interestingly, and contrary to what one would expect from a simple human capital model, participation in voluntary vocational training is not significantly correlated with age for male managers. One possible explanation that reconciles this finding with human capital theory is a proportional and equivalent decrease in the marginal utility of vocational training and the company's offer of (mandatory) vocational training, resulting in unsatisfied demand for vocational training. This residual demand is satisfied by voluntary vocational training, and appears to be constant over time. These results could reflect the fact that throughout the managerial career, voluntary vocational training is used to satisfy changing training needs, but in a constant way.

For female managers, participation in voluntary vocational training does decline with age, so the mechanism proposed for male managers does not apply. The "classical" human capital logic (shorter period of return on training reduces incentives to invest) is more consistent with this finding. The concave age profile suggests that young women delay training, possibly in anticipation of career interruption (Duncan et Hoffman, 1979) while women over 40 see declining benefits to training. In particular when compared to the constant age effect for men, the latter finding suggests some element of systemic discrimination: (older) women see less opportunity of career advancement ("glass ceiling"), or have weaker career aspirations than both men of the same age and younger women.

In regard to organizational tenure, both the somewhat convex seniority profile and the higher absolute voluntary vocational training incidence for women can be interpreted as the result of compensating for the discriminatory practices by over qualifying. As women acquire experience in an organization, the more aware they become of discriminatory practices, and one way to account for or overcome this "soft" glass ceiling is through higher voluntary vocational training.

As for schooling, results point to a stronger positive link for male managers' participation. In line with the theory of systemic discrimination, these results suggest that due to the presence of the glass ceiling phenomenon, women are less likely than men to invest in their human capital when they have obtained a graduate degree since an additional investment in training would become too demanding versus the perceived probability of obtaining benefits (e.g., a promotion). Knowing that female managers are generally localized in lower management levels (Hsieh and Winslow, 2006; Maume, 2004), these results could reflect the limit of the strategy of "over-qualification".

This study had three specific objectives. The first objective was to test the differential effect of human capital variables (age, schooling, and organizational tenure) on the participation of male and female managers 
involuntary vocational training, using data from a national survey. Renaud, Morin and Cloutier (2006) have demonstrated that predictors of participation in voluntary vocational training were different for men and women managers. Specifically, their results indicated a differential effect for three human capital variables (age, schooling, and organizational tenure). Our findings also support a differential effect and suggest that the marginal utility allocated by men and women to voluntary vocational training is different. However, similarities between results end here: whether it is age, organizational tenure or schooling, the nature of the differential effect that we have established does not confirm the results from Renaud, Morin and Cloutier (2006).

The second objective of our study was to empirically test the hypothesis whereby voluntary vocational training has a compensatory role for women. According to this hypothesis, women take voluntary vocational training to compensate for their limited access to mandatory training. Our results confirm this hypothesis. The fact of having received mandatory training is more negatively linked to the participation of female managers in voluntary vocational training than it is for male managers. For male managers, receiving mandatory training has no influence on their likelihood of participating in voluntary training - consistent with voluntary vocational training being a complement, but not a substitute for mandatory training. For female managers, on the other hand, mandatory training is negatively linked to voluntary vocational training. This suggests that female managers use voluntary vocational training, at least partially, to compensate for the lack of mandatory training. Voluntary training constitutes a parallel strategy aimed at mitigating discrimination based on sex for training purposes.

The third objective dealt with obstacles to participating in voluntary vocational training. It attempted to establish the differential effect of family responsibilities by sex. Our results show that having children aged 12 or less is significantly and negatively related to participation in voluntary vocational training but only for female managers. In addition, the presence of a spouse has a positive link to the probability of female participation. These results are in line with the work-family conflict theory. Together, the work-family conflict variables are those which best explain the participation of female managers in voluntary vocational training.

In short, results generally show that predictors of participation in voluntary vocational training differ according to gender. They suggest that men and women participate in different proportions in voluntary vocational training because they have different motivations and face different constraints. Table 3 presents the probability in participating in voluntary vocational training according to different manager profiles and versus the differential effect of predictors by gender. 
TABLE 3

Variation in the Predicted Probability ${ }^{a}$ for Participation in Voluntary Vocational Training

\begin{tabular}{|c|c|c|}
\hline & $\begin{array}{c}\text { Male } \\
\text { managers }\end{array}$ & $\begin{array}{c}\text { Female } \\
\text { managers }\end{array}$ \\
\hline Average probability (sample mean) & $7.30 \%$ & $11.70 \%$ \\
\hline $\begin{array}{l}\text { Predicted probability for typical manager (sample mean) } \\
\text { Manager aged between } 40 \text { and } 49 \text {, with high school } \\
\text { diploma or less, with } 10 \text { years of organisational tenure, } \\
\text { without mandatory training, with spouse, without child }\end{array}$ & $3.75 \%$ & $9.30 \%$ \\
\hline $\begin{array}{l}\text { Predicted probability for manager with typical female manager } \\
\text { characteristics (female sample mean) } \\
\text { Manager aged between } 40 \text { and } 49 \text {, with undergraduate } \\
\text { degree, with } 9,38 \text { years of organizational tenure, with } \\
\text { mandatory training, with spouse, without child }\end{array}$ & $5.87 \%$ & $13.85 \%$ \\
\hline $\begin{array}{l}\text { + Without mandatory training } \\
+ \text { Without spouse } \\
+ \text { With child(ren) aged } 5 \text { and under }\end{array}$ & $\begin{array}{l}9.46 \% \\
9.46 \% \\
9.46 \%\end{array}$ & $\begin{array}{r}22.36 \% \\
4.42 \% \\
1.89 \% \\
\end{array}$ \\
\hline $\begin{array}{l}\text { Predicted probability for manager with typical male manager } \\
\text { characteristics (male sample mean) } \\
\text { Manager aged } 50+\text {, with high school diploma or less, with } \\
10,37 \text { years of organizational tenure, without mandatory } \\
\text { training, with spouse, without child } \\
\end{array}$ & $2.69 \%$ & $2.46 \%$ \\
\hline $\begin{array}{l}\text { Highest predicted probability for female manager } \\
\text { Female manager aged between } 30 \text { and } 39 \text {, with } \\
\text { undergraduate degree, with } 9,38 \text { years (mean) of } \\
\text { organizational tenure, without mandatory training, with } \\
\text { spouse, without child aged } 12 \text { or less }\end{array}$ & - & $41.58 \%$ \\
\hline $\begin{array}{l}\text { Highest predicted probability for male manager } \\
\text { Male manager aged between } 30 \text { and 39, with graduate } \\
\text { degree }\end{array}$ & $17.84 \%$ & - \\
\hline
\end{tabular}

${ }^{a}$ Probability $=\mathrm{e}^{\mathrm{g}(\mathrm{x})} /\left(1+\mathrm{e}^{\mathrm{g}(\mathrm{x})}\right)$, where $\mathrm{g}(\mathrm{x})=$ constant $+\left(\sum \beta \mathrm{x}\right)$. In the preceding formula, zeros were imputed for non significant coefficients.

\section{CONCLUSION}

What variables predict the participation of men and women managers in voluntary vocational training? Why do women managers have a greater participation rate than men? A review of the literature points out the lack of studies on the subject, save for a study by Renaud, Morin and Cloutier (2006) in the banking sector. Our study contributes to the advancement of knowledge since it is the first empirical study which aims to identify predictors of participation in voluntary vocational training for men and women, respectively, using national data. The three pursued objectives 
were to: 1) verify the differential effect of the human capital variables, 2) empirically verify if voluntary vocational training has a compensatory role for women and, 3) verify if family responsibilities constitute a determinant for participation in voluntary vocational training.

Globally, findings suggest that men and women have different motivations for participating in voluntary vocational training and are faced with different constraints. Results have shown that the characteristics linked to a manager's productivity (age, organizational tenure, schooling), mandatory training and family responsibilities are associated with the probability of participating in voluntary vocational training. Specifically, results have shown that the higher rate of participation for women is explained mainly by the differential effect produced by the variables in relation to the gender. In brief, predictors of participation in voluntary vocational training for managers differ for men and women, which confirms the results obtained by Renaud, Morin and Cloutier (2006). Thus, the different characteristics of male and female managers are not the sole reason that they participate in different proportions in voluntary vocational training. It is mostly because they allocate a different cost/benefit ratio to voluntary vocational training and because female managers have to handle constraints linked to family responsibilities that male managers do not have to deal with.

What encourages men and women to participate in voluntary vocational training? What are the constraints that men and women have to deal with? The results show that schooling is the sole human capital variable linked to the probability of male managers taking part in voluntary vocational training. However, the probability that female managers take voluntary vocational training depends on: 1) age, 2) organizational tenure, 3) schooling, 4) mandatory training, 5) having at least one child under the age of 12 and 6) having a spouse. The difference between the participation of men and women in voluntary vocational training can be explained by the differential effect of productivity variables (age, organizational tenure, schooling), the compensatory character of voluntary vocational training for female managers and the constraints of family responsibilities that affect them. Generally, our results corroborate the theory of systemic discrimination and the theory of work-family conflict.

In line with the theory of systemic discrimination, results obtained for age and schooling suggest lower expected returns from voluntary vocational training for female managers. With respect to tenure, results suggest that women use voluntary vocational training as part of a strategy aimed to counter the effects of systemic discrimination in their work place (through over-qualification). To better understand why female managers participate more in voluntary vocational training than male managers, it would be 
relevant to concentrate research on the objectives which female and male managers aim to reach through voluntary vocational training.

Our results confirm the hypothesis formulated by Renaud, Morin and Cloutier (2006) concerning the compensatory role of voluntary vocational training for women. In line with the theory of systemic discrimination, results suggest that women participate in voluntary vocational training in order to compensate for the mandatory training that they did not obtain from their employer. From this perspective, training offered to women (mandatory training) would be less than their request for training (training needs), when both variables of the equation are measured by dummy variables (i.e. having received or not any training during the twelve previous months). Future research should test this hypothesis by taking into account the number of hours of training (voluntary vocational training and mandatory training) including the relevance of mandatory training received versus real training needs.

Finally, our findings support the work-family conflict theory. Results suggest that family responsibilities are a greater obstacle to participating in voluntary vocational training for female managers than for male managers. However, the presence of a spouse allows women to lessen their family responsibilities and allocate the time required to pursue their training, which takes place outside of working hours. For men, family responsibilities have little influence on the work-family conflict. Considering the fact that a greater number of men assume family responsibilities, have men developed specific strategies allowing them to better manager their family responsibilities and voluntary vocational training?

In a broader perspective, our results raise the question of the relevance of voluntary vocational training in organizations. We know that more and more companies encourage their managers to develop their skills through voluntary vocational training. However, this type of training increases the work-family conflict, particularly for female managers. Considering that their management tasks are already very demanding, this could thus contribute to fatigue. Further, in the present context where good managers are often hard to find, where women are increasingly occupying management positions and where working hours are increasing, organizations should question themselves about the indirect costs of voluntary vocational training. Are organizational savings from less mandatory training and development greater than the potential costs linked to fatigue, burn out, low performance, turnover and other intangible work-related variables? Future research should consider the effects of voluntary vocational training and the cost/benefit ratio of this type of training for companies. 


\section{REFERENCES}

Arulampalam, W., A. L. Booth and M. L. Bryan. 2007. "Is There a Glass Ceiling Over Europe? Exploring the Gender Pay Gap across the Wage Distribution." Industrial and Labor Relations Review, 60 (2), 163-186.

AUCC (Association OF UNIVERSITIES AND COLLEGES OF CANADA). 2007. Trends in Higher Education - Volume 1: Enrolment. Ottawa, Ont.: AUCC.

BAKER, M. and N. M. ForTin. 2004. "Comparable Worth in Decentralized Labour Market: The Case of Ontario." Canadian Journal of Economics, 37 (4), 850-862.

BeCKeR, G. 1962. "Investment in Human Capital: A Theoretical Analysis." Journal of Political Economy, 70, 9-49.

Bianchi, S. M., M. A. Milkie, L. C. Sayer and J. P. Robinson. 2000. "Is Anyone Doing the Housework? Trends in the Gender Division of Household Labor." Social Forces, 79 (1), 191-228.

BIRDI, K., C. Allan and P. WARR. 1997. "Correlates and Perceived Outcomes of 4 Types of Employees Development Activity." Journal of Applied Psychology, 82, 845-857.

BlaU, F. D. and L. M. KAHN. 2006. "The U.S. Gender Pay Gap in the 1990s: Slowing Convergence." Industrial and Labor Relations Review, 60 (1), 45-66.

BоотH, A. L. 1991. "Job-Related Formal Training: Who Receives It and What Is It Worth?" Oxford Bulletin of Economics and Statistics, 53 (3), 281-295.

Снicha, M. T. 1997. L'équité salariale: mise en oeuvre et enjeux. Cowansville, Qué.: Éditions Yvon Blais.

DoERINGer, P. and M. J. PIORE. 1971. Internal Labor Markets and Manpower Analysis. Lexington, DC: Heath.

DunCAN, G. J. and S. HofFMAn. 1979. "On-the-Job Training and Earnings Differences by Race and Sex." Review of Economics and Statistics, 61, 594-603.

Eby, L. T., W. J. Casper, A. Lockwood, C. Bordeaux and A. Brinley. 2005. "Work and Family Research in IO/OB: Content Analysis and Review of Literature (1980-2002)." Journal of Vocational Behavior, 66, 124-197.

Ginther, D. K. and K. J. HAYES. 2003. "Gender Difference in Salary and Promotion for Faculty in the Humanities 1977-95." Journal of Human Resources, 38 (1), 34-40.

GoldsteIn, I. L. and K. J. FORD. 2002. Training in Organizations, $4^{\text {th }}$ ed. Belmont, Calif.: Wadsworth-Thomson Learning.

Grant, M. and D. P. Hugues. 2007. Learning and Development Outlook 2007: Are We Learning Enough? Toronto, Ont.: Conference Board of Canada.

GreEn, F. 1993. "The Determinants of Training of Male and Female Employees in Britain." Oxford Bulletin of Economics and Statistics, 55 (1), 103-123.

Greenhaus, J., S. Parasuraman, C. Granrose, S. Rabinowitz and N. Beutell. 1989. "Sources of Work-Family Conflict among Two-Career Couples." Journal of Vocational Behavior, 34, 133-153. 
GundERSON, M. 2006. "Viewpoint: Male-Female Wage Differentials: How Can That Be?" Canadian Journal of Economics, 39 (1), 1-21.

HsieH, C. W. and E. WinsLOW. 2006. "Gender Representation in the Federal Workforce." Review of Public Personnel Administration, 26 (3), 276.

LORECH, K., J. RuSSEL and M. RuSH. 1989. "The Relationships among Family Domain Variables and Work-Family Conflict for Men and Women." Journal of Vocational Behavior, 35, 288-308.

MARK, S. 1977. "Multiple Roles and Role Strain: Some Notes and Human Energy, Time and Commitment." American Sociological Review, 42, 921-936.

MARShALL, K. 2006. "Convergence des rôles des sexes." L'Observateur Économique Canadien, 19 (8), 3.1-3.12.

Maume, D. J. 2004. "Is the Glass Ceiling a Unique Form or Inequality? Evidence from a Random-Effects Model of Managerial Attainment." Work and Occupations, 31 (2), 250.

Maurer, T. J. and B. A. TARulli. 1994. "Investigation of Perceived Environment, Perceived Outcome, and Person Variables in Relationship to Voluntary Development Activity by Employees." Journal of Applied Psychology, 79 (1), 3-14.

Maurer, T. J. and L. M. Shore. 2002. "Perceived Beneficiary of Employee Development Activity: A Three-Dimensional Social Exchange Model." Academy of Management Review, 27 (3), 432-444.

McDowell, J. M., L. D. Singell and J. P. ZiliaK. 2001. "Gender and Promotion in the Economics Profession." Industrial and Labor Relations Review, 54 (2), 224-245.

Miller, P. W. 1994. "Gender Discrimination in Training: An Australian Perspective." British Journal of Industrial Relations, 32 (4), 539-565.

NoE, R. A. 1996. "Is Career Management Related to Employee Development and Performance?" Journal of Organizational Behavior, 17, 119-133.

NoE, R. A. 2005. Employee Training and Development. $3^{\text {rd }}$ ed. New York, NY: McGraw-Hill.

Olson, C. A. and B. E. Becker. 1983. "Sex Discrimination in the Promotion Process." Industrial and Labor Relations Review, 36 (4), 624-642.

OOSTERBEEK, H. 1998. "Unravelling Supply and Demand Factors in WorkRelated Training." Oxford Economic Papers, 50 (2), 266-284.

Renaud, S., L. Morin and J. Cloutier. 2006. "Participation in Voluntary Training Activities in the Canadian Banking Industry: Do Gender and Managerial Status Matter?" International Journal of Manpower, 27 (7), 666-678.

Swimmer, G. 1990. "Gender Based Differences in Promotions of Clerical Worker." Relations Industrielles/Industrial Relations, 45 (2), 300-310.

Statistics Canada. 2003. "Guide to the Analysis of the Workplace and Employee Survey." Catalogue No. 71-221-GIE. Ottawa, Ont.: Statistics Canada. 
Statistique CANAdA. 2002. Le "qui, quoi, quand et où" des écarts salariaux entre les hommes et les femmes. La série sur le milieu de travail en évolution. Ottawa, Ont.: Statistique Canada.

St-Onge, S., M. Audet, V. Haines and A. Petit. 2004. Relever les défis de la gestion des ressources humaines. $2^{\mathrm{e}}$ éd. Boucherville, Qué.: Gaëtan Morin Éditeur.

Tharenou, P. 2001. "The Relationship of Training Motivation to Participation in Training and Development." Journal of Occupational and Organizational Psychology, 74, 599-621.

VoYDANOFF, P. 1988. "Work Role Characteristics, Family Structure Demands, and Work-Family Conflict." Journal of Marriage and the Family, 50, 749-761.

Wexley, K. N. and G. P. Latham. 2002. Developing and Training Human Resources in Organizations. $3^{\text {rd }}$ ed. Upper Saddle River, NJ: Prentice Hall.

\section{RÉSUMÉ}

Les déterminants de la participation à la formation professionnelle volontaire : une étude auprès de cadres féminins et masculins dans les entreprises canadiennes

Dans de nombreuses entreprises canadiennes, les travailleurs sont de plus en plus encouragés par leur employeur à se développer par euxmêmes de façon volontaire, hors des activités de formation obligatoire. Ce type particulier de formation externe réfère à la formation professionnelle volontaire (vocational voluntary training). Il existe très peu d'études portant sur les déterminants de la participation à la formation professionnelle volontaire. Les travaux de Renaud, Morin et Cloutier (2006) figurent parmi les rares études à s'être penchées sur la question. Réalisée au sein d'une organisation du secteur bancaire canadien, leur étude révèle notamment que les femmes cadres présentent une probabilité plus élevée de participer à la formation professionnelle volontaire que leurs homologues masculins. Elle met également en évidence l'effet différencié selon le sexe des facteurs de productivité (ex. : âge, scolarité, nombre d'années de service). En vue d'expliquer la participation supérieure des femmes à ce type de formation, ces mêmes chercheurs ont avancé l'hypothèse selon laquelle les femmes utiliseraient ce type de formation pour compenser le manque de formation obligatoire.

À partir des données nationales de l'Enquête sur le milieu de travail et les employés (EMTE) (Workplace and Employee Survey - WES) de Statistique Canada, notre étude vise à identifier les déterminants de la 
participation à la formation professionnelle volontaire de cadres masculins et féminins, respectivement. Trois objectifs spécifiques sont visés : 1) vérifier l'effet différencié des facteurs de capital humain (âge, scolarité, années de service) sur la participation des cadres masculins et féminins grâce à des données nationales, ce qui assure une meilleure généralisation des résultats, 2) vérifier empiriquement si la formation professionnelle volontaire joue un rôle compensatoire pour les femmes, et 3) élargir le modèle d'analyse aux obstacles à la formation professionnelle volontaire en vérifiant empiriquement l'influence qu'exercent les responsabilités familiales.

En s'appuyant sur la théorie du capital humain, la théorie de la discrimination systémique et la théorie du conflit travail-famille, six hypothèses de recherche ont été formulées. Les résultats d'une régression logistique indiquent que la scolarité, le nombre d'années de service et le fait d'avoir un conjoint(e) améliorent la probabilité des cadres de participer à la formation professionnelle volontaire. En revanche, l'âge et le fait d'avoir au moins un enfant d'âge préscolaire ont une influence négative sur la participation. De plus, lorsque l'on contrôle l'effet de ces variables, les femmes demeurent plus susceptibles de suivre de la formation professionnelle volontaire que les hommes.

Les résultats montrent ainsi que la participation plus importante des femmes à la formation professionnelle volontaire ne s'explique pas entièrement par le fait que les hommes et les femmes possèdent des caractéristiques différentes (facteurs de productivité, formation obligatoire et responsabilités familiales). À ce chapitre, les résultats des régressions logistiques respectivement effectuées pour les hommes et les femmes montrent que la différence de participation observée s'explique largement par l'effet différencié qu'exercent ces caractéristiques. Pour les hommes, la scolarité constitue la seule variable liée significativement à la probabilité de participer à la formation professionnelle volontaire. Pour les femmes, la probabilité de suivre ce type de formation varie en fonction : 1) de l'âge, 2) du nombre d'années de service, 3) du niveau de scolarité, 4) de la participation à la formation obligatoire, 5) du fait d'avoir au moins un enfant de moins de 12 ans et 6) du fait d'avoir un conjoint(e). Ces résultats suggèrent que les hommes et les femmes cadres font une évaluation différente de l'utilité marginale de la formation professionnelle volontaire et qu'ils font face à des contraintes différentes.

Pour les femmes, les résultats suggèrent ainsi que les jeunes femmes retarderaient leur investissement dans la formation professionnelle volontaire parce qu'elles anticipent d'interrompre leur carrière pour se consacrer à la maternité. En lien avec la théorie de la discrimination systémique, les résultats suggèrent que les femmes plus âgées participeraient moins à ce type de formation parce qu'elles percevraient moins de possibilités 
d'avancement de carrière, ou parce qu'elles auraient des aspirations de carrière plus limitées comparativement aux femmes plus jeunes et aux hommes. Toujours en lien avec la théorie de la discrimination systémique, les résultats obtenus en regard des années de service suggèrent que, pour les femmes, la formation professionnelle volontaire s'inscrirait dans une stratégie visant à contrer les effets des pratiques discriminatoires de leur employeur à travers la surqualification. Les résultats obtenus concernant le niveau de scolarité sont également cohérents avec la théorie de la discrimination systémique.

Par ailleurs, les résultats suggèrent que les femmes participeraient à la formation professionnelle volontaire notamment pour compenser la formation obligatoire qu'elles n'ont pas reçue de leur employeur. La formation professionnelle volontaire constituerait alors une stratégie parallèle visant à pallier la discrimination fondée sur le sexe en matière de formation. Enfin, les résultats indiquent que les responsabilités familiales constituent un obstacle significatif pour les femmes, ce qui corrobore la théorie du conflit travail-famille. Dans l'ensemble, les variables liées aux responsabilités familiales sont celles qui expliquent le mieux la participation des femmes à la formation professionnelle volontaire. 